Йосепчук Н. Музей родинних професій (м. Івано-Франківськ): становлення, Аіяльність

УДК 7.71.069

DOI https://doi.org/10.24919/2308-4863/34-2-22

\author{
Надія ЙОСЕПЧУК, \\ orcid.org/0000-0003-3113-8179 \\ аспірант кафедри образотворчого і декоративно-прикладного \\ мистеитвва та реставраиіiі \\ Прикарпатського начіонального університету \\ імені Василя Стефаника \\ (Івано-Франківськ, Україна) уоsерсhиk778@gmail.com
}

\title{
МУЗЕЙ РОДИННИХ ПРОФЕСІЙ (М. ІВАНО-ФРАНКІВСЬК): СТАНОВЛЕННЯ, ДІЯЛЬНІСТЬ
}

\begin{abstract}
У статті висвітлено діяльність надзвичайно оригінального і чи не єдиного в Украӥні такого роду музею, де представлена історія одного роду. Експозиція музею розповідає про 150 родинних професій, якими впродовж останніх двохсот років володіли члени родини головного ініціатора і засновника музею, заслуженого журналіста України, почесного громадянина Івано-Франківська - Романа Фабрики. Автором простежено шлях, який було пройдено власником і засновником від задуму до відкриття музею. Проаналізовано експонати, які зберігаються у фондах, особливо цінними відзначені ті, які датуються кінцем ХІХ-початку XX століття. Саме до таких належить семафор (засіб сигналізації на залізниці) $і$ давні ліхтарі, які використовували також залізничники, адже представників саме иүієї професії в родині налічується найбільше. Загальний залізничний стаж у родині Фабрик уже перевищує 300 років, саме тому в музеї налічується найбільиа кількість речей, пов 'язаних із роботою залізничників. У музеї зосереджено сотні інструментів, апаратів, механізмів, пристроїв, предметів побуту, одяг тошо. Унікальним родинним експонатом, який виготовили 200 років тому австрійські майстри, $\epsilon$ світильник $i$ такого ж віку ваги, ше збереглися в родині дружини. Цікавою є і особистість самого засновника музею й основного зберігача, реставратора і оповідача історії Романа Фабрики. Він був представником Укрінформу на Прикарпатті, лауреат численних журналістських премій, автор фотоальбому про украйнців, щзо жили на територіі Польщчі, а потім були депортовані («Лемки: роки і долі»). Саме п. Роман десять років прачюював на Українському радіо, стояв біля джерел створення міського телебачення, автор циклу програм «Вечірній Івано-Франківськ». У Музеї родинних професій представлено відреставровані плуг $i$ борону, старовинну прялку і керамічний посуд, художнє ткаитво і ковальські інструменти, давній пристрій для смаження кавових зерен $і$ домашній млин жорна, за допомого яких жорнували збіжжя. Це музей, експонати якого наділені семантичним значенням, а деякі навіть становлять певну сакральність для родини Фабрики. У стінах музею проводяться иікаві екскурсії, дискусї̈, відкриті лекиї та уроки, які популяризують духовну культуру і регіональну спадщину поколінь, а також виступають скарбничями історичної пам'яті.
\end{abstract}

Ключові слова: музей, експозиція, родинні професії, духовна спадщина

\author{
Nadiia YOSEPCHUK, \\ orcid.org/0000-0003-3113-8179 \\ Graduate Student at the Department of Fine Arts and Decorative \\ and Applied Art and Restoration \\ Vasyl Stefanyk Precarpathian National University \\ (Ivano-Frankivsk,Ukraine) yosepchuk778@gmail.com
}

\section{MUSEUM OF FAMILY PROFESSIONS (IVANO-FRANKIVSK): ESTABLISHMENT, ACTIVITY}

The article covers the activities of an original and the only museum of that kind in Ukraine, where the history of one family is presented. The exposition of the museum demonstrates about 150 family professions, which for the last two hundred years belonged to the family of the main initiator and founder of the museum, honored journalist of Ukraine, honorary citizen of Ivano-Frankivsk - Roman Fabryka. The author traces the way taken by the owner and founder from the idea to the opening of the museum. The exhibits stored in the holdings of the museum are analyzed, especially those dated to the end of the XIX to the beginning of the XX century, and include the semaphore (a means of signaling on the railway) and ancient lanterns, which were also used by railway workers, because there are the most representatives of this profession in the family. The museum has the largest number of items related to the work of railway workers. Hundreds of tools, devices, mechanisms, devices, household items, clothes, etc. are exhbited in the museum. A unique family exhibit made 200 years ago by Austrian craftsmen is a lamp of the same age and weight. The personality of the museum's founder and main custodian, restorer and storyteller Roman Fabryka is also interesting. He was a representative of Ukrinform in Prykarpattia, a laureate of numerous journalistic awards, the author of a photo album about Ukrainians who lived in 
Poland and were later deported ("Lemkos: years and destinies"). Mr. Roman had been work in the Ukrainian Radio for ten years, was one of the originators of city television, the author of the series of programs "Evening Ivano-Frankivsk". The Museum of Family Professions presents a restored plow and harrow, an ancient spinning wheel and ceramic utensils, artistic weaving and blacksmithing tools, an ancient device for roasting coffee beans and a domaniy mill - a millstone used to grind grain. Interesting excursions, discussions, open lectures and lessons that will promote the spiritual culture and regional heritage of generations, are conducted in the museum.

Key words: museum, exposition, family professions, spiritual heritage.

Постановка проблеми. Інтерес до музеїв та до музейної справи у XXI ст. почав набирати обертів. Про це свідчить і чимала кількість літератури, яка 3'явилась саме у 2000-х pp., і наукові розвідки, які стосуються як великих та відомих музеїв, так і значно менших, обласних, регіональних тощо. Наше наукове дослідження стосується досить специфічного і невеликого, навіть сімейного, музею, але не менш цікавого в культурологічному аспекті. Адже в колекції музею містяться цінні й автентичні експонати, опис яких уперше виноситься на загал. Навіть більше, у результаті опрацювання джерельної бази, яка складається здебільшого з невеликих статей у періодиці, нами не виявлено повноцінного наукового дослідження щодо даного об'єкта.

Аналіз досліджень. Під час дослідження було опрацьовано літературу та джерела, де частково висвітлюються діяльність та проблема музейництва на Прикарпатті. Надзвичайно інформативною $є$ стаття I. Чмелик «Музеї Прикарпаття та їх роль у навчально-виховній та науковій діяльності студентської молоді» (Чмелик, 2015), де досліджено проблематику музейництва в культурному житті Івано-Франківщини. Охарактеризовано роботу музеїв відповідно до специфіки мистецьких процесів у регіональному аспекті. У розвідці Н. Бабій «Альтернативний музей міста в умовах інформаційного суспільства: Івано-Франківський досвід» (Бабій, 2019) проаналізовано роль актуальних практик, що популяризують і сприяють успішності музейних закладів. Значну увагу тут приділено і Музею родинних професій, особливість якого полягає в особистому сприйнятті кожного відвідувача.

Загалом, до проблематики музейництва й особливо зберігання музейних фондів зверталися такі науковці: М. Аронець (Аронець, 2010), Н. Доскалюк (Доскалюк, 2015), О. КанарськаЛуцкан (Канарська-Луцкан, 2010), В. Мельник (Мельник, 2005), М. Откович (Откович, 2007), Т. Откович (Откович, 2013), М. Паньків (Паньків, 2001), Т. Петрів (Петрів, 2015), М. Пушкар (Пушкар, 2017), М. Якібчук (Якібчук, 2005) та інші.

Завдяки можливостям засобів масової інформації та розширенню спектра інтернет-ресурсів дані щодо заснування й окремі аспекти діяльності
Музею родинних професій можна почерпнути із цих джерел. Однак інформації щодо цінних експонатів, які зберігаються в колекціях, немає.

Мета статті - висвітлити діяльність Музею родинних професій, проаналізувати специфіку та виявити мистецьку цінність експонатів, які зберігаються в колекціях, а також розкрити роль Музею в культурному житті краю.

Виклад основного матеріалу. Музей родинних професій - унікальний і чи не єдиний в Україні такого роду, де вся увага сконцентрована на професіях однієї родини, експонати, які представлені, наочно ілюструють приналежність кожного iї члена до певного роду діяльності.

Передусім у статті хотілось би висвітлити особистість основного ініціатора, колекціонера та незмінного засновника протягом усього існування музею, а цього року виповнюється вже 15 років iз дня заснування, - Романа Фабрики. Член Національної спілки журналістів України, заслужений журналіст України, багатолітній репортер місцевого та республіканського радіомовлення, фундатор телебачення в Івано-Франківську, власкор Укрінформу в Івано-Франківській області і патріот. Адже кожен українець повинен знати свій родовід. Бо саме через нього передаються звичаї й обряди рідного народу, саме так його схарактеризував один із місцевих репортерів (Садовий, 2012). Окрім цього, Роман Михайлович - автор циклу програм «Вечірній Івано-Франківськ», ініціатор трьох персональних виставок - «Америка в Галичині», «Кличуть у гори трембіти», «Лемки: роки i долі». Нині він редагує газету Івано-Франківської облспоживспілки «Кооперація Прикарпаття», завершує роботу над книгою «Історія споживчої кооперації Прикарпаття» й активно дописує до наших «Вістей < ..>» $\mathrm{i}$ «Вістей $<\ldots>$ ДВ» тощо.

Музей відкрито 13 вересня 2005 р. У музейній експозиції, розміщеній у спеціально спорудженому приміщенні на невеликому подвір'ї, практично в центрі Івано-Франківська, зібрано атрибути 150 професій, освоєних представниками родини Фабрик протягом двохсот років, а також предмети побуту. Своє дітище автор побачив уві сні, саме в той час, коли він був народжений, i вважає це певним символізмом, який посприяв створенню Музею. 
Головний девіз музею - «Від плуга до комп'ютера», ці два експонати також наявні в колекції. А ще, окрім таких основних експонатів, як: каски, посуд, рахівниця, опудала різних тварин, гасова лампа, примус, праски для грубої і тонкої тканин, теле- та радіолампи, куделя, борона тощо, $\epsilon$ ті, якими особливо пишається автор. До таких належать жорна, саме з їхньою допомогою в давні часи жорнували збіжжя. Р. Фабрика зазначає: «Технічний прогрес, електрика, енергетика, машинобудування запропонували людям більш ефективні пристрої, млини, круподерки тощо. Нині колишні жорна вийшли 3 ужитку. Вони віджили свій вік. I добре, що деякі газди про всяк випадок заховали свої ручні млинки, що й забули місця схову $<\ldots>$ Але пригадую, траплялися й такі бабусі, що ні за яку ціну не бажали розпрощатися зі своїми годувальницями» (Фабрика, 2008).

Одним із найцікавішими і найдавніших з експонатів Музею родинних професій пан Роман уважає пристрій перемелювання кавових зерен. Подібні млинки сто років тому виготовляла англійська компанія "KBS" і постачала в Індію. Потроху вони розійшлися і Європою. У наш час вони трапляться хіба що на американських антикварних форумах. Окрім цього, $є$ ще кілька млинків у колекції музею для ручного перемелювання зерен кави. Ще однією гордістю колекції є пилка, якій понад 130 років. Привіз ії колись із важких заробітків із Філадельфії прадід дружини. Примандрувала через океан і металева пічка, на якій вибито напис "American Union" - «Американський Союз».

Оскільки однією з основних і почесних професій родини Р. Фабрики був фах залізничника, то відповідно й багато знарядь праці, пов'язаних із цією професією: залізничні квитанції різних часів, давні ліхтарі та семафор кінця XIX початку XX ст. Загалом родина віддала сталевій магістралі більше 300 років життя.

Р. Фабрика - досвідчений колекціонер, який пильно і ретельно вивчає, досліджує і збирає предмети наукового та культурного вжитку. У його арсеналі можна побачити колекції фотоапаратів, мінералів, книжкових мініатюр, екслібрисів, поштових марок, монет, дзвіночків й антикварних тарелів.
У музеї зосереджено сотні інструментів, пристроїв, механізмів, апаратів, предметів побуту, різноманітне домашне начиння, посуд, одяг. Серед унікальних експонатів - родинний, виготовлений 200 років тому австрійськими майстрами, світильник і такого ж віку ваги, що збереглися в родині дружини Оксани. Були в родині Фабрик і кооператори, які стояли біля витоків руху в Галичині ще на початку минулого століття. У пам'ять про це в музеї $\epsilon$ експонати із крамниць тогочасних споживчих кооперативів, а також перших молочарських кооперативів на Львівщині, звідки й тягнеться родовід. Збереглися згадки про пасічників, архітекторів, агрономів, зоотехніків, учителів, садівників, геологів, лісорубів, пожежників, кіномеханіків, фотографів. Загалом у музеї представлено життя та побут населення України в межах однієї родини з 1805 p. до 2020 р. За час існування музею його оглянули понад шість тисяч відвідувачів, серед яких журналісти, краєзнавці, викладачі, студенти та школярі.

Висновки. Декілька років знадобилось Р. Фабрикові для того, щоб мрія стала реальністю, але йому це вдалося. Багато часу і зусиль було витрачено на реставрацію, збирання й упорядкування експонатів, але саме завдяки копіткій праці й ентузіазму власника Музей родинних професій входить у п'ятірку унікальних приватних українських музеїв. За ним закріпився титул «не скучного», а навпаки, «живого» музею, де можна почути детальну розповідь про всі 150 професій, доторкнутись до історії та культури наших предків, відчути атмосферу того часу для кращого розуміння, усвідомлення та важливості збереження в період мультикультуралізму національних традицій. Також це хороша платформа для створення майстер-класів, круглих столів, бесід, дискусій, регіональних семінарів, воркшопів для музейників, етнографів, мистецтвознавців, істориків, студентів, школярів та всіх зацікавлених людей.

Отже, уважаємо, що такого роду культурні проєкти мають розвиватись, знаходити відповідну підтримку, виходити за рамки патерну класичних музеїв, шукати неординарні шляхи та рішення для збереження та популяризації національної ідеї в культурний простір як України, так і Європи загалом.

\section{СПИСОК ВИКОРИСТАНИХ ДЖЕРЕЛ}

1. Аронець М. 2007-й - рік майстра Пінзеля. Івано-Франківський обласний художній музей: експлікація буття. Історія формування колекиії, експозиційно-виставкова діяльність 2006-2009 рр. До 30-річчя заснування музею. Івано-Франківськ : Даурія, 2010. С. 28-30.

2. Арсенюк I. Родина, родина, від батька й до сина <..>. Хобi : журнал. Лютий. 2007. С. 46-51.

3. Бабій Н. Альтернативний музей міста в умовах інформаційного суспільства: Івано-Франківський досвід. Питання культурологіï. № 35. С. 108-122. DOI: 10.31866/2410-1311.35.2019.188794.

4. Гончарук I. Фабрика ремесел Романа Фабрики. Високий замок : газета. 22 травня 2012. 
5. Доскалюк Н. Досвід експозиційної діяльності в Музеї мистецтв Прикарпаття. Роль музею у збереженні, реставрації та популяризаџії культурного надбання : матеріали Всеукраӥнської науково-практичної конферениї з нагоди 35-ліття заснування Музею мистеитв Прикарпаття, 8-9 вересня 2015 p. Івано-Франківськ : СІМИК, 2015. С. 114-118.

6. Канарська-Луцан О. Іконографічні особливості ікони «Іван Хреститель з житієм» із церкви Зішестя Святого Духа в Рогатині. Ікона «Іван Хреститель з житієм». Середина XVI cm. // Музей-пам'ятка архітектури і живопису XVI-XIX ст. Церква Зішестя Святого Духа в Рогатині. Філіал Івано-Франківського обласного художнього музею. Львів, 2010. С. 46-78.

7. Мельник В. Івано-Франківський художній музей : Експлікація буття. Івано-Франківський художній музей : Експлікація буття. Історія формування колекиії, експозиційно-виставкова діяльність, бібліографія публікацій. 1980 2005. До 25-річчя заснування музею. Івано-Франківськ : Нова Зоря, 2005. С. 5-20.

8. Музей родинних професій : вебсайт. URL: http://museum.profession.org. ua/ (дата звернення: 07.09.2020).

9. Откович М. Золоті сторінки меценатства. 2002-2007 pp. : каталог відреставрованих творів. Івано-Франківськ : видавець Третяк І. Я., 2007. С. 4.

10. Откович Т. Мистецько-стилістичні особливості іконостаса 1650 р. із церкви Зішестя Святого Духа в Рогатині та його історія. Рогатинська Святодухівська иерква крізь призму історії : матеріали Науково-практичної конференції до 30-річчя у статусі музею-пам'ятки дерев'яної архітектури і живопису XVI-XIX ст., Рогатин, 22 вересня 2013 р. Івано-Франківськ : СІМИК, 2013. С. 40-50.

11. Паньків М. Намітки з історії Івано-Франківського краєзнавчого музею. Наукові записки Краєзнавчого музею. Івано-Франківськ : Місто НВ, 2001. Вип. 5-6. С. 223-231.

12. Петрів Т. Формування колекції музею-церкви Зішестя Святого Духа в Рогатині. Роль музею у збереженні, реставрації та популяризації культурного надбання : матеріали Всеукраїнської науково-практичної конференції $з$ нагоди 35-ліття заснування Музею мистецтв Прикарпаття, 8-9 вересня 2015 р. Івано-Франківськ : СІМИК, 2015. С. $26-30$.

13. Пушкар М. Збірка сакрального мистецтва Музею мистецтв Прикарпаття. Історія релісії в Україні : науковий щорічник. 2017. Вип. 27. Ч. 2. С. 207-215.

14. Садовий М. 3 родоводу Романа Фабрики. Магістраль : газета. 2012. № 55.

15. Фабрика Р. Жорна голодного дитинства. Репортер: газета. 2008. № 6.

16. Чмелик І. Музеї Прикарпаття та їх роль у навчально-виховній та науковій діяльності студентської молоді. Гірська школа Українських Карпат. 2015. № № 12-13. С. 276-280.

17. Шалкітене І. Під омофором Миколая Чудотворця. City life : журнал. 2007. № 1.

18. Якібчук М. Історія розвитку Івано-Франківського художнього музею. Музеї, колекції, люди: традиції $і$ перспективи розвитку музейної справи. Вітчизняний $і$ зарубіжний досвід : матеріали Міжнародної науково-практичної конференції в рамках святкування 25-річчя музею, Івано-Франківськ, Художній музей, 10-11 листопада 2005 р. Івано-Франківськ : Гостинець, 2005. С. 84-85.

\section{REFERENCES}

1. Aronets M. 2007 - rik majstra Pinzelya [2007 - the year of the master Pinzel]. Ivano-Frankivsk Regional Art Museum: explication of existence. History of the collection formation, exposition-exhibition activity of 2006-2009. To the 30'th anniversary of the museum foundation. Ivano-Frankivsk: Dauria, 2010. P. 28-30; [in Ukrainian].

2. Arsenyuk I. Rody'na, rody'na, vid bat'ka j do sy'na $<\ldots>$ [Family, family, from father to son...] Hobby Magazine. February. 2007. P. 46-51; [in Ukrainian].

3. Babiy N. Al'ternaty'vny'j muzej mista v umovax informacijnogo suspil'stva: Ivano-Frankivs'ky'j dosvid [Alternative city museum in the conditions of information society: Ivano-Frankivsk experience]. Questions of culturology, (35), $108-122$. doi: https://doi.org/10.31866/2410-1311.35.2019.188794; [in Ukrainian].

4. Goncharuk I. Fabry'ka remesel Romana Fabry'ky' [Farika crafts Roman Fabrika]. The newspaper "High Castle". For May 22. 2012; [in Ukrainian].

5. Doskalyuk N. Dosvid ekspozy'cijnoyi diyal'nosti v Muzeyi my'stecztv Pry'karpattya [Experience of exposition activity in the Museum of Arts of Prykarpatya]. The role of the museum in preservation, restoration and popularization of cultural heritage: materials of the All-Ukrainian scientific and practical conference (on the occasion of the 35th anniversary of the founding of the Museum of Arts of Prykarpattia), September 8-9, 2015. Ivano-Frankivsk: SIMIK, 2015. P. 114-118; [in Ukrainian].

6. Kanarska-Lutsan O. Ikonografichni osobly’vosti ikony' "Ivan Khresty’tel' z zhy’tiyem” iz cerkvy' Zishestya Svyatogo Duxa v Rogaty'ni [Iconographic features of the icon "John the Baptist with life" from the Church of the Descent of the Holy Spirit in Rohatyn]. Icon "John the Baptist with life". The middle of the XVI century. Museum-monument of archival texture and painting of the XVI-XIX centuries. Church of the Descent of the Holy Spirit in Rohatyn. Branch of the Ivano-Frankivsk Regional Art Museum. Lviv, 2010. P. 46-78; [in Ukrainian].

7. Melnyk V. Ivano-Frankivskyi khudozhnii muzei: Eksplikatsiia buttia [Ivano-Frankivsk Art Museum: Explication of existence]. Ivano-Frankivsk Art Museum: Explication of existence. Is-theory of collection formation, exposition-exhibition activity, bibliography fia publications. 1980-2005. To the 25'th anniversary of the museum. Ivano-Frankivsk: Nova Zorya, 2005. P. 5-20; [in Ukrainian].

8. Muzei rodynnykh profesii [Museum of family professions]. Website. URL: http://museum.profession.org. ua / (appeal date: 07.09.2020); [in Ukrainian].

9. Otkovich M. Zoloti storinky metsenatstva [Golden pages of patronage]. 2002-2007: [catalog of restored works]. Ivano-Frankivsk: Publisher Tretyak I. Ya., 2007. P. 4; [in Ukrainian]. 
10. Otkovych T. Mystetsko-stylistychni osoblyvosti ikonostasa 1650 roku iz tserkvy Zishestia Sviatoho Dukha v Rohatyni ta yoho istoriia [Artistic and stylistic features of the iconostasis of 1650 from the Church of the Descent of the Holy Spirit in Rohatyn and its history]. Proceedings of the scientific-practical conference "Rohatyn Holy Spirit Church through the prism of history" (to the 30'th anniversary of the museum - monuments of wooden architecture and painting of the XVI-XIX centuries). Rohatyn, September 22. 2013. Ivano-Frankivsk: SIMIK, 2013. P. 40-50; [in Ukrainian].

11. Pankiv M. Namitky z istorii Ivano-Frankivskoho kraieznavchoho muzeiu [Namitky z istorii Ivano-Frankivskoho krajeznavchoho muzeyu]. Naukovi zapiski Krayeznavchoho muzeyu. Ivano-Frankivsk: City of NV, 2001. Issue. 5-6. P. 223231; [in Ukrainian].

12. Petriv T. Formuvannia kolektsii muzeiu-tserkvy Zishestia Sviatoho Dukha v Rohatyni [Formation of the collection of the museum-church of the Descent of the Holy Spirit in Rohatyn]. The role of the museum in preservation, restoration and popularization of cultural heritage: materials of the All-Ukrainian scientific and practical conference (on the occasion of the 35 'th anniversary of the founding of the Museum of Arts of Prykarpattia), September 8-9, 2015. Ivano-Frankivsk: SIMIK, 2015. P. 26-30; [in Ukrainian].

13. Pushkar M. Zbirka sakralnoho mystetstva Muzeiu mystetstv Prykarpattia [Zbirka sakralnoho mystetstva Muzeiu mystetstv Prykarpattia Collection of sacred art of the Museum of Arts of Prykarpattia]. History of religion in Ukraine: scientific yearbook. 2017. Vip. 27. Ch. 2. Pp. 207-215; [in Ukrainian].

14. Sadovy M. Z rodovodu Romana Fabryky [From the pedigree of Roman Fabryka]. The Magistral newspaper. For 25-31.07.2012. № 55; [in Ukrainian].

15. Factory R. Zhorna holodnoho dytynstva [Mill of hungry childhood]. Reporter newspaper. For February 7, 2008. № 6; [in Ukrainian].

16. Chmelyk I. Muzei Prykarpattia ta yikh rol u navchalno-vykhovnii ta naukovii diialnosti studentskoi molodi [Museums of Prykarpattia and their role in educational and scientific activity of student youth]. Mountain school of the Ukrainian Carpathians. № 12-13 (2015). S. 276-280; [in Ukrainian].

17. Shalkitene I. Pid omoforom Mykolaia Chudotvortsia [Under the omophorion of Nicholas the Wonderworker]. City life magazine. 2007. № 1; [in Ukrainian].

18. Yakibchuk M. Istoriia rozvytku Ivano-Frankivskoho khudozhnoho muzeiu [History of the Ivano-Frankivsk Art Museum]. Proceedings of the international scientific-practical conference "Museums, collections, people: traditions and prospects for the development of museum business. Domestic and foreign experience" in celebration of the 25 'th anniversary of the museum. Ivano-Frankivsk, Art Museum, November 10-11, 2005. Ivano-Frankivsk: Gostynets, 2005. P. 84-85. [in Ukrainian]. 